\title{
Mass-balance variability as a base for interpreting ice-core data
}

\author{
V. N. Mikhalenko \\ Institute of Geography, Russian Academy of Sciences, Staromonetny 29, Moscow 109017, Russia
}

\begin{abstract}
The spatial extrapolation of data from ice cores depends on the complexity of the glacier system where the drilling site is located. The correlation between net mass balance, $b_{11}$, of a specific point and of the whole glacier is different for each point. Analysis of net mass balance of Tuyuksu glacier in the Tien Shan, central Asia, confirms that the distribution of mass balance with height is more-or-less constant from year to year except in years with extreme values of $b_{n}$. Two types of "similarity" are described, additive and multiplicative. The "similarity" changes gradually from additive at the peripheral parts of the Tien Shan to multiplicative in the most continental central and eastern parts. Glacier mass-balance fluctuations of the frontal ridges are connected to the oscillations of accumulation and consequently to precipitation. Where the climate is more continental the mass-balance variability depends much more on the melting conditions than on accumulation. For the spatial interpretation of ice-core drilling results, a special analysis of "similarity type" is necessary. It allows the fixing of the spatial borders of the glacier system for which the drilling site is representative.
\end{abstract}

\section{INTRODUCTION}

Data from accumulation areas of glaciers can give information relevant to different fields of science.

The spatial interpretation of ice-core results depends a lot on the complexity of the glacier system drilled. The most important factor is the location of the drilling site. The spatial variability of mass-balance components in the glacier system is also significant.

\section{LOGATION OF THE DRILLING SITE}

Accumulation and precipitation estimated from a mountain glacier ice core are representative only of a limited area around the drilling site. In contrast to Antarctic and Greenland ice sheets, isolines of the mass balance of the mountain glaciers have a complicated character Haeberli and Herren, 1991), depending on the surface topography, proximity to surrounding ranges and other factors. The simplest mass-balance isolines are found in circular ice caps and domes.

Consider the 35 year record of the Tuyuksu valley glacier in the Tien Shan, central Asia. Mass balance measured in the four upper zones of the glacier $\left(b_{\text {uii }}\right)$ and over the whole glacier $\left(b_{\text {ng }}\right)$ were correlated (see Fig. 1). That in the top zone, where steep slopes surround the glacier basin, correlates worst of all with the balance of the whole glacier. Towards the middle part of the glacier (i.e. towards the equilibrium-line altitude), $b_{\text {ni }}$ becomes closer to $b_{\text {ng }}$ as indicated by the angle of curves in Figure 1 . The $b_{\text {ni }} / b_{\text {ng }}$ correlation coefficient increases at the same time. Mass balance of this zone is equal to the mass balance of the whole glacier.

Such correlations are not identical for every glacier. In each case it is necessary to consider the ratio between $b_{\text {ni }}$ at the drilling site and $b_{\text {ng }}$ of the whole glacier or glacier system. Two important problems arise:

1. Is there a relation (linear in the simplest case) which allows the transfer of correlations from one field to another, and is the relation stable in time? Researchers analyzing the ice-cores suppose that such similarity occurs.

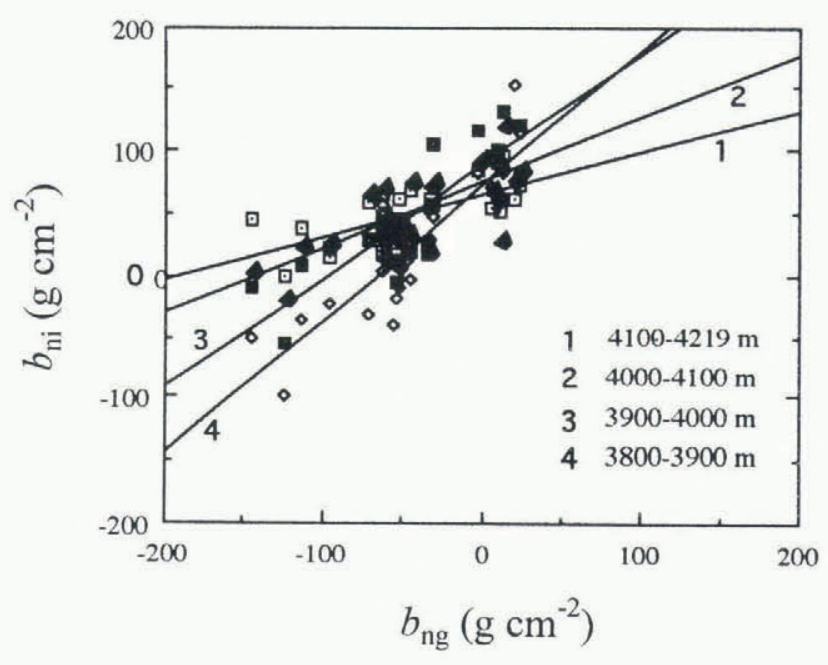

Fig. 1. Relation between net mass balance of different parts of the accumulation area of Tuyuksu glacier, $b_{\mathrm{ni}}$, and average net mass balance of the whole glacier, $b_{\mathrm{ng}}$. 
2. How do the mass-balance components of separate glaciers change within the borders of a glacier system?

\section{SIMILARITY OF MASS-BALANCE FIELDS}

Similarity of mass-balance fields (position of isolines of net mass balance at the glacier) was first mentioned by Ahlmann (1948). He found that the annual mass-balance curves $\left(b_{\mathrm{n}}\right.$ vs altitude) of the southern Norwegian glaciers were parallel in different years. Thus the mass balance for any one year can be determined by observing only one site if the shape of the mass-balance curve is known. Meier (1962) considered the parallel balance curves of South Cascade Glacier to be a common peculiarity of all glaciers. Lliboutry (1974) worked out a more general model and postulated that the temporal variations of mass balance were similar from one point to another. This model was extrapolated to an overall glacier system where the individual glacier data were taken as points (Reynaud, 1980; Reynaud and others, 1986). The same method was applied to compare the temporal variability of glacier mass balance in the Alps, Scandinavia and the Tien Shan (Reynaud and others, 1984). There was an attempt to analyze statistically the annual balance curves and to check the hypothesis on the parallelism of the balance curves. Dyurgerov and others (1989) ascertained that this parallelism does not hold for all glaciers.

The mass-balance field is determined mainly by the accumulation field which is determined by the glacier surface topography. The ablation field is more regular and depends mainly on altitude. There can be two representations ("similarity types") of the mass-balance field according to Kunakhovitch (1991). The "additive similarity" is typical of relatively low glaciers and maritime glaciers. Its characteristic is parallelism of the mass-balance curves. The "multiplicative similarity" is typical of continental glaciers and those which occupy a large altitude range. Figure 2 shows examples of both.

The "additive similarity" from year to year of the mass-balance field of Tuyuksu glacier can be seen in Figure 3. However, as mentioned by Kuhn (1986), in some extreme years the character of additivity is broken. The correlation coefficient $r$ between the balance curves for different years was used as a criterion of additive similarity (Table 1). Values of $r$ less than 0.900 were taken as extreme cases. Examples are years with extremely negative mass balance $(1978,1984)$ or extremely positive mass balance $(1969,1981)$. They correspond well with Kuhn's conclusion.

\section{VARIABILITY IN A GLACIER SYSTEM}

It is difficult to find a glacier system where the massbalance field is uniform over all glaciers. Glaciers in different parts of a mountain region react variously to climate changes. For example, warming in southern Norway led to positive balances for coastal glaciers from 1961 till 1990 but to negative balances for inland glaciers (Dyurgerov and Mikhalenko, 1989).

Four glaciers in the Tien Shan have been observed for more than 30 years (see Fig. 4). The observations allow

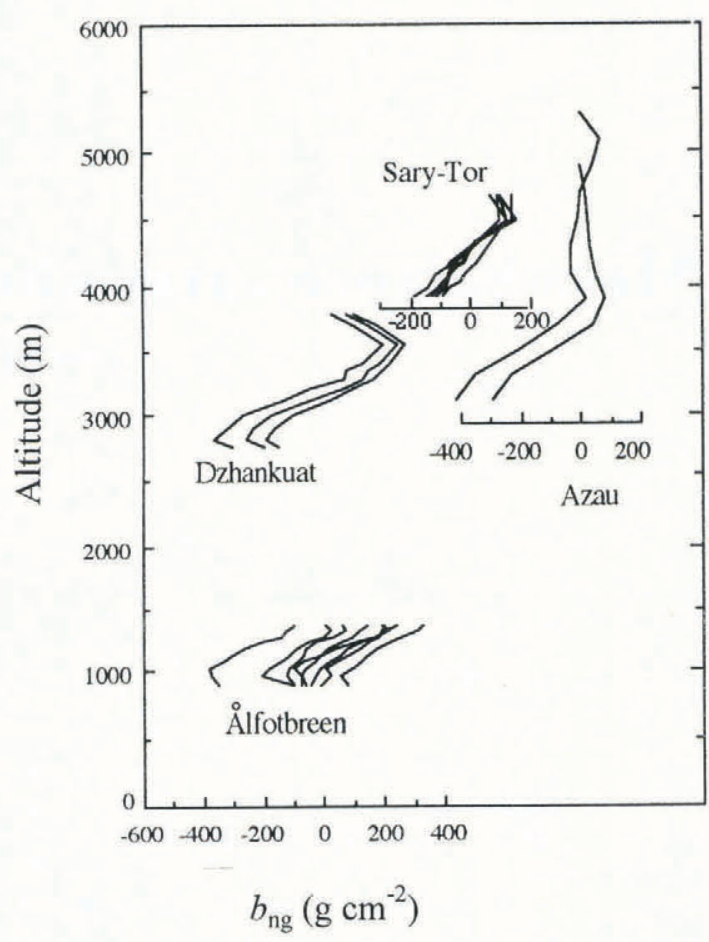

Fig. 2. Typical mass-balance curves for Alfotbreen (southern Norway), Dzhankuat (central Caucasus), Azau (Elbrus massif, central Caucasus) and Sary-Tor

(Tien Shan interior) glaciers.

both the temporal variability of accumulation and ablation and changes in spatial characteristics to be considered.

The largest negative mass balances and annual variability are along the ridges in the northern and western Tien Shan which have the greatest precipitation (Table 2). The relation between accumulation and ablation for the three glaciers observed the longest is shown in Figure 5. They have had a negative balance for the last 30 years. The absolute mass balance decreases gradually towards the centre, reaching the minimum negative value at glacier No. 1. This is because summer precipitation increases as one goes towards glaciers which are more continental. Also, the "similarity type" changes from "additive" to "multiplicative" as the glaciers become more continental.

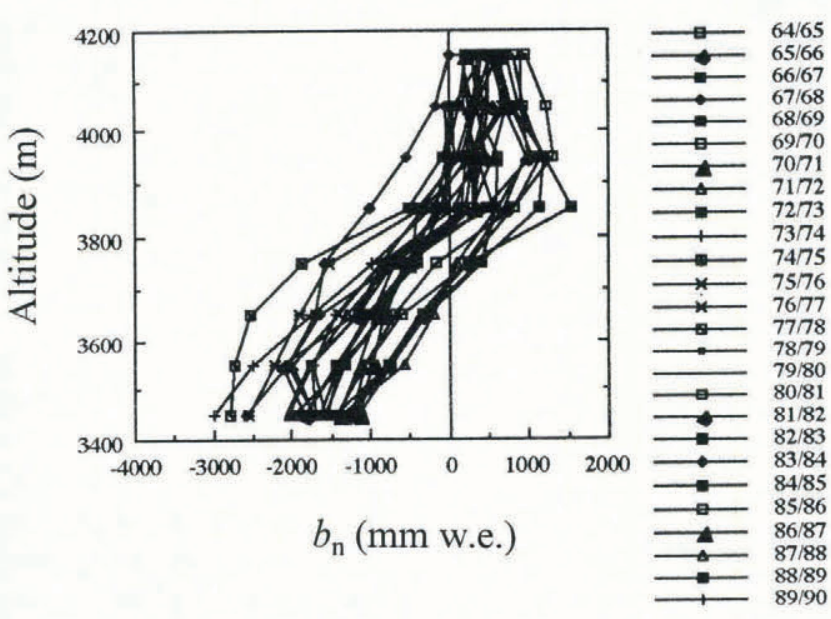

Fig. 3. Mass-balance curves for Tuyuksu glacier, 1964-90. 


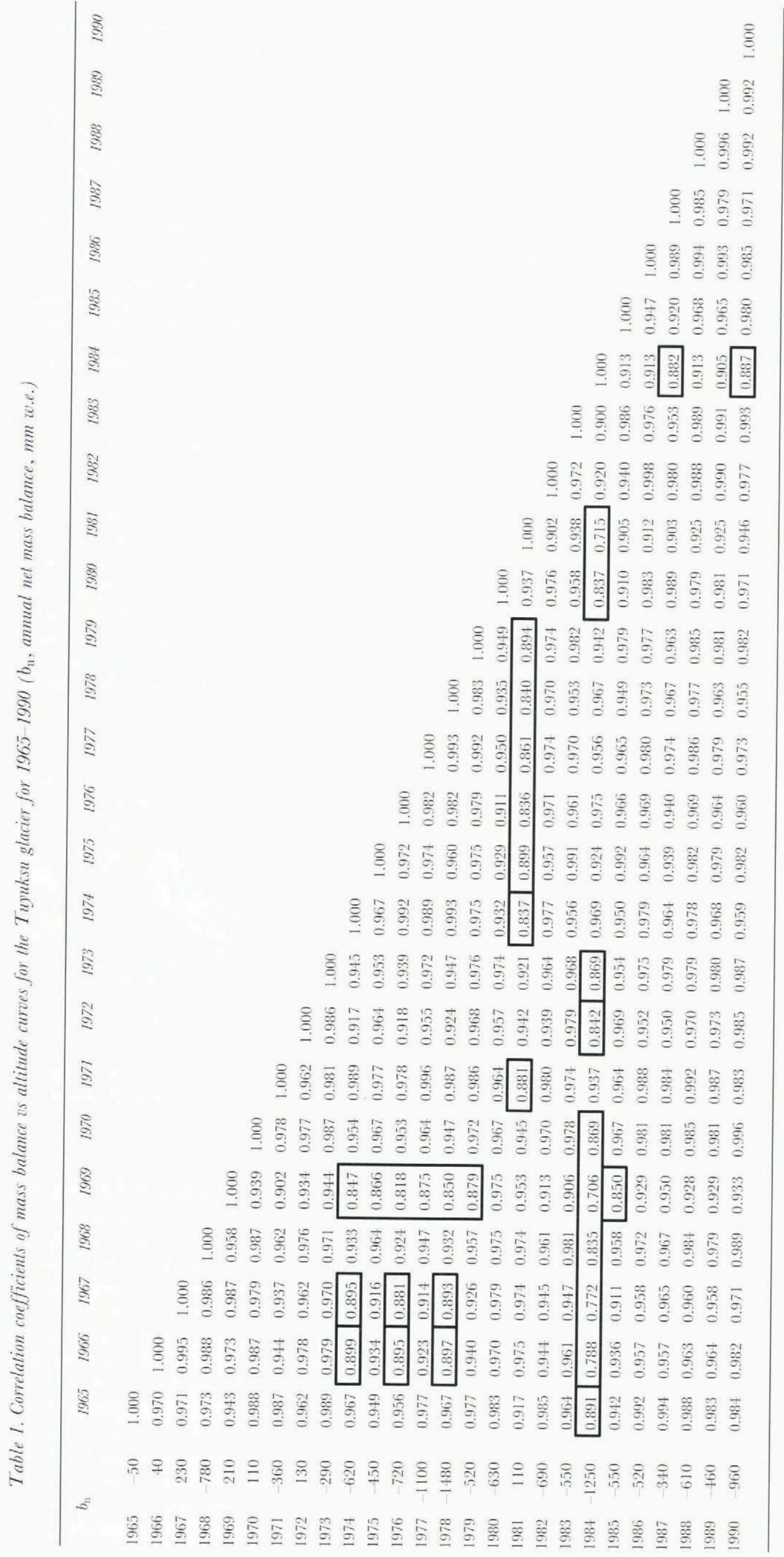




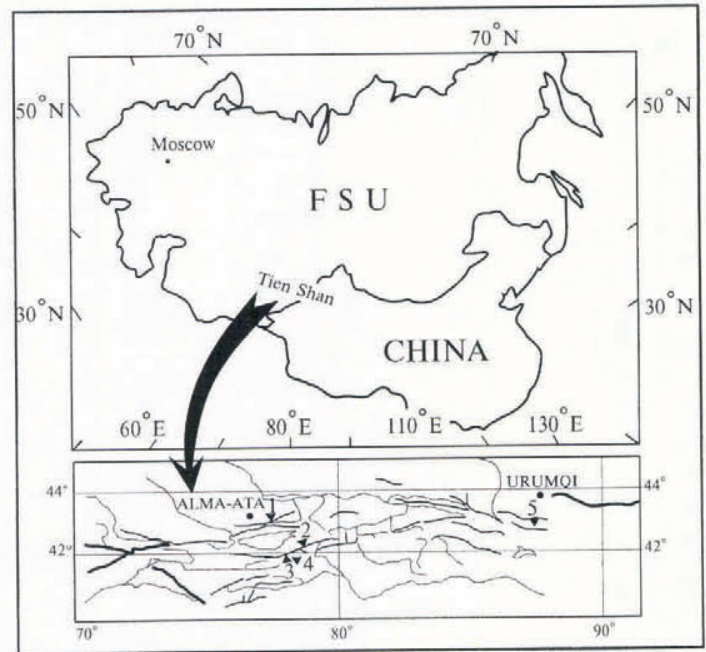

Fig. 4. Locations of the investigated glaciers: 1, Tuyuksu; 2, Karabalkak; 3, Gregoriev; 4, Sary-Tor; 5, glacier No. 1.

Table 2. Mass-balance components of the Tien Shan glaciers: $c_{\mathrm{t}}$ annual net accumulation; $a_{\mathrm{t}}$ annual net ablation; $b_{\mathrm{n}}$ annual net mass balance (mmw.e.)

\begin{tabular}{|c|c|c|c|c|c|c|c|c|c|}
\hline \multirow[b]{2}{*}{ Year } & \multicolumn{3}{|c|}{ Tuyuksu } & \multicolumn{3}{|c|}{ Karabalkak } & \multicolumn{3}{|c|}{ Glacier No.l } \\
\hline & $c_{\mathrm{t}}$ & $a_{t}$ & $b_{\mathrm{n}}$ & $c_{\mathrm{t}}$ & $a_{\mathrm{t}}$ & $b_{\mathrm{n}}$ & $c_{\mathrm{t}}$ & $a_{\mathrm{t}}$ & $b_{\mathrm{n}}$ \\
\hline 57 & 1070 & -1220 & -150 & 548 & -579 & -31 & & & \\
\hline & 1250 & 920 & 330 & 728 & -666 & 62 & & & \\
\hline 59 & 970 & -1390 & -420 & 737 & -1081 & -344 & 543 & -456 & 87 \\
\hline 60 & 1090 & -1190 & -100 & 666 & -957 & -291 & 608 & -796 & -188 \\
\hline 61 & 920 & -1480 & -560 & 474 & -1280 & -806 & 630 & -663 & -33 \\
\hline & 870 & -1560 & -690 & 656 & -742 & -86 & 624 & -791 & -167 \\
\hline & 1290 & -850 & 440 & 666 & -706 & -40 & 633 & -399 & 235 \\
\hline & 1320 & -800 & 52 & & -7 & 144 & 589 & -587 & 2 \\
\hline & 1160 & -12 & -5 & 711 & -75 & -4 & 50 & -276 & 375 \\
\hline 1 s & 1120 & -10 & 40 & 879 & -1035 & -156 & 11 & -885 & -374 \\
\hline 1 s & 1280 & -10 & 230 & 796 & -78 & & 08 & 678 & -69 \\
\hline 1s & 810 & -159 & -780 & 613 & -126 & -652 & 545 & -1001 & -457 \\
\hline 1 s & 1210 & -1000 & 210 & 665 & -6 & & 47 & -499 & 148 \\
\hline & 1130 & -10 & 1 & 619 & $-8 c$ & -18 & 39 & -852 & -313 \\
\hline & 0 & -1 : & 3 & & -5 & 14 & 25 & -523 & 102 \\
\hline & 970 & -8 & 1 & & -557 & & 69 & -407 & 262 \\
\hline 1 & 1010 & -1300 & -290 & 496 & -1249 & $-7:$ & 503 & -1211 & -707 \\
\hline 1 & 790 & -1410 & -620 & 632 & -68 & -51 & 606 & -720 & -24 \\
\hline 1 & 950 & -1400 & -450 & 505 & -98 & -475 & 747 & -459 & 306 \\
\hline & 780 & -1500 & -720 & 444 & -128 & -841 & 17 & -488 & 29 \\
\hline & 850 & $-1 s$ & -11 & 371 & -1 & $-8 t$ & 14 & -534 & 180 \\
\hline & 790 & -2270 & $-14 i$ & & -1582 & -11 & 441 & -551 & -110 \\
\hline & 930 & -1450 & -52 & 573 & -1074 & -501 & ;2 & -5 & -76 \\
\hline & 880 & -1510 & -6 & 0 & -1 & -3 & 390 & -725 & -337 \\
\hline 1 & 1100 & - & & 577 & -1024 & -447 & 536 & -1188 & -655 \\
\hline 1982 & 890 & -1580 & $-6 !$ & 323 & -1107 & -784 & 656 & -701 & -49 \\
\hline 198 & 1170 & -1720 & -53 & 211 & -1159 & -948 & 668 & -568 & 96 \\
\hline 1 & 710 & -1960 & -1250 & 235 & -1807 & -1572 & 455 & -538 & -83 \\
\hline 98 & 770 & -1320 & -550 & 263 & -1555 & -1292 & 478 & -1090 & -612 \\
\hline 1986 & 1130 & -1650 & -52 & & -1055 & & 482 & -1151 & -669 \\
\hline 1987 & 930 & -1270 & -3 & 32 & -1 & -6 & 474 & -650 & -175 \\
\hline 00 & 1090 & -17 & -61 & 91 & -1247 & -456 & 463 & -1106 & -644 \\
\hline 1 & 820 & -1280 & -46 & 691 & -1087 & -396 & 578 & -473 & 108 \\
\hline 199 & 920 & -1880 & -960 & 730 & -1508 & -778 & 596 & -544 & \\
\hline 1991 & & & & & & & 456 & -1162 & -706 \\
\hline 1992 & & & & & & & 605 & -587 & 18 \\
\hline & & 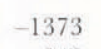 & -374 & 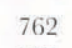 & -1160 & -398 & 565 & -704 & -135 \\
\hline & 169 & 349 & 48 & 175 & 314 & 435 & 88 & 262 & 308 \\
\hline$U_{v}$ & 0.17 & -0.25 & -0.13 & 0.23 & -0.27 & -1.09 & 0.16 & -0.37 & -2.27 \\
\hline
\end{tabular}

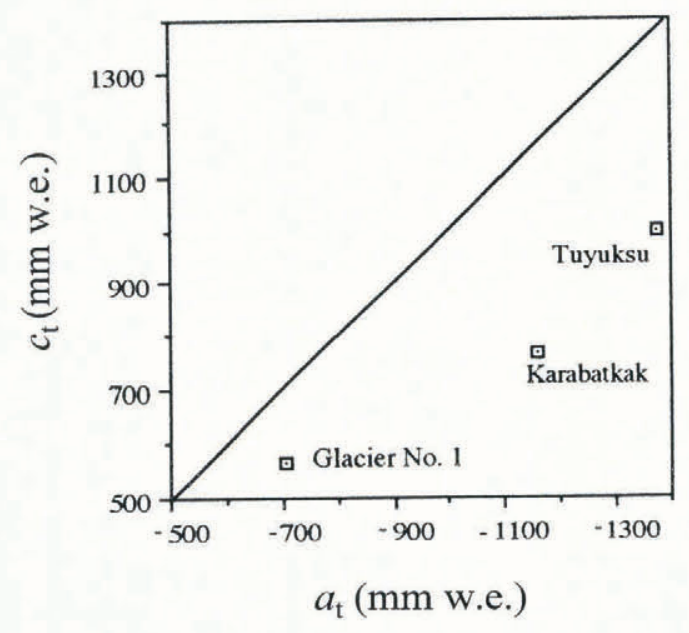

Fig. 5. Relation between annual net accumulation $c_{\mathrm{t}}$ and anmual net ablation $a_{\mathrm{t}}$ of the Tien Shan glaciers, 1959-90.

The characteristic mass-balance curves for some glaciers are shown in Figure 6. The "additive similarity" is observed at all altitudes for Tuyuksu glacier. For the Gregoriev ice cap in the Tien Shan interior, the additive similarity is observed in the ablation zone, and the multiplicative similarity in the accumulation zone. The similarity type becomes closer to the additive in years of negative mass balance and to the multiplicative in years of positive mass balance.

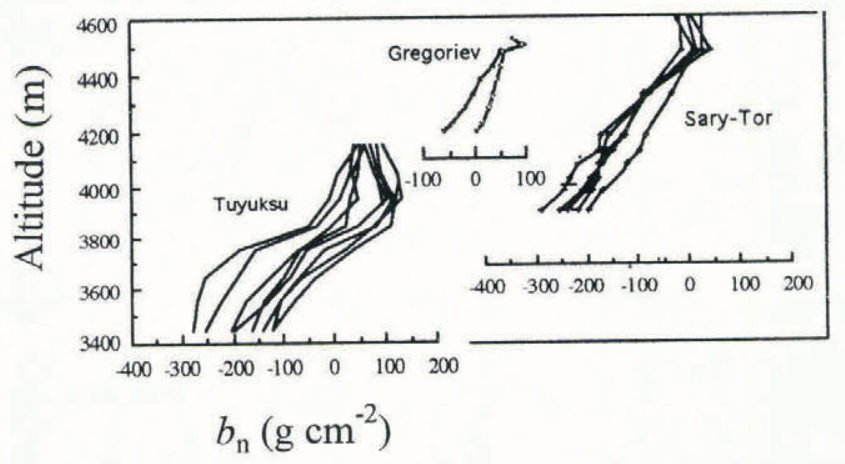

Fig. 6. Change of similarity type of mass-balance field of the Tien Shan glaciers from the periphery to the interior part of the mountain system.

In general, it can be said that all maritime glaciers are "additive", while continental glacier systems can be a mixture of "additive" and "multiplicative" glaciers. Therefore, correlations between maritime glaciers will be stronger (and operate over larger areas) than will the correlations associated with continental glaciers (Table 3 ).

The contribution of ablation variation to the annual mass balance is greatest for glacier No. 1 and is typical of the continental eastern Tien Shan. It is shown by the correlation triangle of Figure 7. The lengths of its sides are proportional to the standard deviation of the corresponding values. The cosine of the angle between any two sides is equal to the correlation coefficient $r$. For example, the cosine of the angle opposite to the base is equal to the correlation between accumulation and ablation. The 
Table 3. Correlation coefficients of annual net mass balance of the Tien Shan glaciers, 1959-90

\begin{tabular}{lccc}
\hline Glacier & Tuyuksu & Karabatkak & Glacier. No. 1 \\
\hline Tuyuksu & 1.000 & & \\
Karabatkak & 0.743 & 1.000 & \\
Glacier No. 1 & 0.075 & 0.238 & 1.000 \\
\hline
\end{tabular}

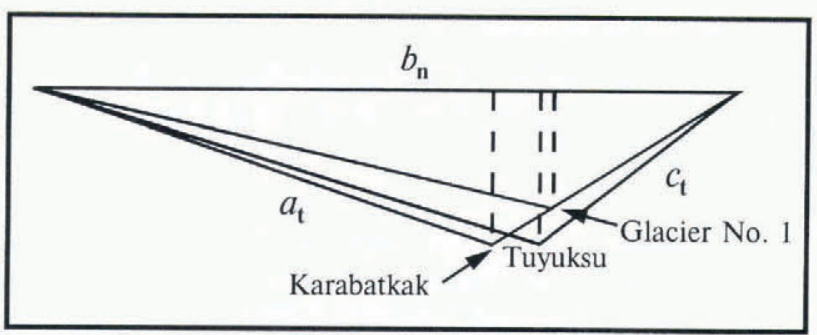

Fig. 7. Input of variability of net accumulation $c_{\mathrm{t}}$ and net ablation $a_{\mathrm{t}}$ of the Tien Shan glaciers into variability of mass balance for the period 195991.

apex projection on the base defines the ratio of accumulation and ablation variabilities contributing to the total mass-balance variability.

In summary, ablation variability is most significant for glacier No. 1, is less for Tuyuksu glacier and is least for Karabatkak glacier (see Fig. 7). The heavier the annual precipitation and the less the input of summer accumulation, the lower is the correlation between annual accumulation and ablation. Nevertheless, the close correlation between accumulation and ablation is typical for all Tien Shan glaciers as both processes occur simultaneously, with the maximum rate in the warm season (Dyurgerov and others, 1994).

\section{CONCLUSIONS}

For the spatial interpretation of ice cores, a special analysis of the "similarity type" of mass balance is necessary. This allows fixing the spatial borders of the glacier system for which the drilling site is representative. Such analyses require special drilling in regions where there are long records of temperature, precipitation and mass balance. These are few. In the former Soviet Union they are the Katyn and Karaugom plateaus in the Caucasus, the Gregoriev and It-Tysh ice caps in the central Tien Shan and the Pamir firn plateau in the central Pamir at an altitude above $6000 \mathrm{~m}$.

\section{ACKNOWLEDGEMENTS}

This study was supported by the Russian Academy of Sciences and U.S. Department of State grant MAB-1753300226. The final draft of the paper was improved by the critical comments of G. Paltridge and an anonymous reviewer.

\section{REFERENCES}

Ahlmann. H.W. 1948. Glaciological research on the North Allantic coasts. London, Royal Geographical Society. Research Series 1.

Dyurgerov, M. B. and V.N. Mikhalenko. 1989. Razvitiye predstavleniy o vneshnem massoobmene lednikovykh sistem: ot lednika $\mathrm{k}$ lednikovoy sisteme [Development of the concept of external mass exchange of glacier systems: from a glacier to a glacier system|. Materialy Glyatsiologicheskikh Issledovamiy 66, 31-38.

Dyurgerov, M.B., G.I. Ol'shanskiy and N. V. Prokhorova, 1989. Izmenchivost' akkumulyatsii ablyatsii gornykh lednikov [Variability of accumulation and ablation of mountain glaciers]. Materialy Glyalsiologicheskikh Issledozaniy 65, 92-102.

Dyurgerov, M.B., V.N. Mikhalenko, M.G. Kunakhovitch, S. N. Ushnurtsev, Liu Chaohai and Xie Zichu. 1994. On the cause of glacier mass balance variations in the Tien Shan mountains. Geo fournal, $332 / 3), 311317$.

Glazyrin, G. Ye and B. V. Kislov. 1984. Ispol'zovanie standartnoi meteorologicheskoi informatsii dlia vydeleniia godovykh sloev $\mathbf{v}$ firnovoledianoi tolshche gornykh lednikov [Using standard meteorological information for the identification of annual layers in mountain glaciers]. Trudy Sredneazialskii Regional'nyi VauchnoIssledovatel'skii Institut, 105, 7992.

Haeberli, W. and E. Herren, eds. 1991. Glacier Mass Balance Bulletin . Vo.I (1988-1989). Wallingford, International Association of Hydrological Sciences International Commission on Snow and Ice; Nairobi. United Nations Environment Programme; Paris, UNESCO.

Kuhn, M. 1986. Meteorological conditions of mass balance extremes. Materialy Glyalsiologicheskikh Issledozaniy 57, 149153.

Kunakhovitch. M. G. 1991. Mountain glacier mass balance: similarity and numerical computation. Abstract of Ph.D. thesis, Moscow. Institute of Geography.

Lliboutry, L. 1974. Multivariate statistical analysis of glacier anmual balances. f. Glaciol. 1369 , 371-392.

Lorius, C: and 6 others. 1985. A 150,000-year climatic record from Antarctic ice. Vature, 316 6029, 591-596.

Meier, M. F. 1962. Proposed definitions for glacier mass budget terms. J. Glaciol., 433 , 252-263.

Reynaud. L. 1980. Can the linear balance model be extended to the whole Alps? International Association of Hydrological Sciences Publication 126 Workshop at Riederalp 1978 World Glacier Inventon 273-284.

Reynaud, L.. M. Vallon, S. Martin and A. Letréguilly, 1984. Spatio temporal distribution of the glacial mass balance in the Alpine. Scandinavian and Tien Shan areas. Geogr. Ann., 66A 3 , 239247.

Reynaud, L.. M. Vallon and A. Letréguilly, 1986. Mass-balance measurements: problems and two new methods of determining variations. f. Glaciol., 32112$), 446454$.

Thompson, L. G. 1993. Reconstructing the paleo ENSO records from tropical and subtropical ice cores. Bulletin de l'Institut Francais d'Etudes Andines, 22 1), 6583. 